\title{
Long-term outcome in fully treated HIV-infected children in West Java-Indonesia: gender differences
}

\author{
Anggraini Alam, Rachmat Sumantri, Ida Parwati, Nanan Sekarwana \\ Department of Pediatrics, Faculty of Medicine, Padjadjaran University, Hasan Sadikin General Hospital, Bandung, Indonesia
}

\begin{abstract}
Introduction: Since the discovery of highly active anti-retroviral therapy (HAART), there is an improvement in virology findings, thus human immunodeficiency virus type 1 (HIV-1)-infected children can grow and thrive properly. Studies have showed successful treatments of HIV-1-infected children in limited resources are differed by gender.

Material and methods: We enrolled children $2-<15$ years old, vertically transmitted, with good treatment adherence and condition, and minimal therapy duration of 6 months. The study has been approved by the Research and Ethics Committee.

Results: One hundred and sixty-eight children were enrolled, 99 were excluded because of lack of adherence and loss to follow-up. As many as 70 children have met the inclusion criteria, 40 (57.1\%) children were females, who started anti-retroviral therapy (ART) therapy at the median age of 8 (range, 2.0-14.0 years). When the therapy started, 45 (64.3\%) children were moderately to severely symptomatic (WHO stage 3 or 4 ), and most of them were males. Meanwhile, boys had higher improvement outcome of CD4 with median $10.5 \%(r=3-45.7 ; p=0.030)$ and lower viral loads than girls, although all HIV viruses were detected below $20 \mathrm{copy} / \mathrm{ml}$. There was no significant relevance between caregiver and the treatment success.

Conclusions: Children in limited resources, especially boys, can achieve successful therapeutic outcome with good treatment adherence and taking medication regardless of the caregiver.
\end{abstract}

HIV AIDS Rev 2018; 17, 4: 267-271 DOI: https://doi.org/10.5114/hivar.2018.80258

Key words: HIV-infected children, gender, outcome.

\section{Introduction}

Human immunodeficiency virus (HIV) cause acquired immune deficiency syndrome (AIDS). Since 1981, 78 million people were infected by HIV-1, with total deaths up to 39 million people [1]. At the end of 2015, 2.6 million children were infected by HIV worldwide, with majority of cases found in Africa, out of which only 32\% receiving anti-retroviral therapy (ART) [2].

Address for correspondence: Dr. Anggraini Alam, Department of Pediatrics, Faculty of Medicine, Padjadjaran University, Hasan Sadikin General Hospital. Jl. Pasteur 38, 40161, Bandung, Indonesia, phone: +62 8122016430 , e-mail: anggialam@yahoo.co.id

Globally, new HIV infections in children aged $<15$ years had declined by $58 \%$ since 2002 to 2013 [3]. However, every 25 minutes, one person gets infected by HIV-1 in Indonesia, making Indonesia the country with the most rapid increased number of cases [4], ranked third in Asia Pacific, after China and India [1]. Prevalence of HIV-infected children is 7\% from all HIV patients in Indonesia, with only 1,228 children receiving ART [5].

Article history:

Received: 19.01.2017

Received in revised form: 15.03.2018

Accepted: 16.04.2018

Available online: 20.11.2018
International Journal of HIV-Related Problem

HIV \& AIDS

R e v i e w 
The best choice to maintain health of HIV-1-infected children is to provide therapy to inhibit viral replication, restore the immune system, and prevent the emergence of opportunistic infections [6].

Since the discovery of highly active anti-retroviral therapy (HAART), there has been improvement in virology findings, thus HIV-1-infected children can grow and thrive properly [8-10]. Survival rate against HIV are increasing in children worldwide and it improves the quality of life in HIV-1-infected children [9-17].

Various studies have shown the long-term outcomes of children receiving antiretroviral therapy [8-10, 17-19] but there are no reports on the successful treatment of HIV-1infected children in Indonesia. It is not easy to get an overview about the therapy efficacy in Indonesia, where only less than half of patients had a good adherence to therapy.

\section{Material and methods}

\section{Study population}

An observational analytical study with cross sectional design was conducted in March to August 2016 in HIV Pediatric Clinic in Dr. Hasan Sadikin Hospital, the top referral hospital in West Java Indonesia. Informed consent was obtained from their caregivers and assent form was obtained from patient $>10$ years old. All patients who met inclusion criteria were enrolled.

Included subjects were children with at least 6-month ARV treatment, with good adherence based on pharmacy record. Caregivers recall and pill counts at scheduled visits were also included in the monitoring of treatment outcome completed every 6 months $[7,8]$.

The exclusion criteria were: 1) hospitalized subjects, based on medical history and physical examination taken on admission; 2) based on medical history and physical examination, subjects with cytomegalovirus, varicella-zoster virus, herpes simplex 1 and 2 virus infection, and hepatitis; malignancy/cancer; 3) on anti-tuberculosis treatment; 4) treated with drugs that affect immunology status in the last 3 months; 5) immunization in the last 2 weeks.

\section{Viral load examination}

Viral load was determined using absolute quantitative real time-PCR. PCR was done using the Primerdesign ${ }^{\mathrm{TM}}$ Genesig ${ }^{\oplus}$ kit for human immunodeficiency virus type 1 (HIV1) genomes. The viral load under $20 \mathrm{copy} / \mathrm{ml}$ was considered undetected.

\section{Statistical analysis}

Continuous variables were expressed as mean and standard deviation or median and range, as appropriate. Categorical data were expressed as proportion. If data was normally distributed, the comparisons were performed using student $t$-test, otherwise Mann-Whitney test was used. $\chi^{2}$ test was
Table 1. Characteristic of subjects $(n=70)$

\begin{tabular}{|c|c|}
\hline Characteristics & $n(\%)$ \\
\hline \multicolumn{2}{|l|}{ Sex } \\
\hline Male & $30(42.9)$ \\
\hline Female & $40(57.1)$ \\
\hline \multicolumn{2}{|l|}{ Age (years) } \\
\hline$<5$ & $15(21.4)$ \\
\hline $5-9$ & $28(40.0)$ \\
\hline $10-14$ & $27(38.6)$ \\
\hline Mean (SD) & $7.9(3.5)$ \\
\hline Median & 8 \\
\hline Range & $2-14$ \\
\hline \multicolumn{2}{|l|}{ HIV stage } \\
\hline I & $13(18.6)$ \\
\hline II & $12(17.1)$ \\
\hline III & $30(42.9)$ \\
\hline IV & $15(21.4)$ \\
\hline \multicolumn{2}{|l|}{ Caregiver } \\
\hline Parents & $48(69.6)$ \\
\hline Grandparents & $12(17.4)$ \\
\hline Others & $9(13.0)$ \\
\hline \multicolumn{2}{|c|}{ Duration of treatment (months) } \\
\hline$\leq 48$ & $40(57.1)$ \\
\hline$>48$ & $30(42.9)$ \\
\hline Median & $49.5(29.2)$ \\
\hline Median & 44 \\
\hline Range & $8-128$ \\
\hline
\end{tabular}

used to analyze categorical data. Sample size was counted using multiple linear regression analysis, with $95 \%$ confidence interval (CI) and power test at $80 \%$. All statistical analysis was done using SPSS 17 for Windows software. $P<0.05$ with two-tailed test was considered statistically significant.

This study was approved by the Research and Ethics Committee of the Universitas Padjadjaran Medical School, Indonesia.

\section{Results}

Ninety-eight patients were excluded because of no adherence and loss to follow-up. There were 70 children enrolled in the study, with good adherence to ART for at least 6 months, based on pharmacy record. Of the 70 children who had completed the treatment and included in the analysis, $40(57.1 \%)$ were females, all children had acquired HIV prenatally, and the median age of ART initiation was 8 years old (range, 2.0-14.0 years). All children had baseline CD4 measured, except for 2 children. Only 2 children had baseline HIV RNA measured. Seventy children were rated with 
Table 2. Comparison of viral load, CD4, and treatment duration

\begin{tabular}{|c|c|c|c|}
\hline \multirow[b]{2}{*}{ Variable } & \multicolumn{2}{|c|}{ Sex } & \multirow[b]{2}{*}{$p$ value $^{\star}$} \\
\hline & $\begin{array}{c}\text { Male } \\
(n=30)\end{array}$ & $\begin{array}{l}\text { Female } \\
(n=40)\end{array}$ & \\
\hline Viral load & & & 0.601 \\
\hline Mean (SD) & $11.2(7.3)$ & $9.2(6.3)$ & \\
\hline Median & 6 & 6 & \\
\hline Range & $5-20$ & $5-20$ & \\
\hline CD4 & & & 0.030 \\
\hline Mean (SD) & $12.9(8.7)$ & $9.5(1.9)$ & \\
\hline Median & 10.50 & 9.71 & \\
\hline Range & $3.0-45.7$ & $4.1-13.6$ & \\
\hline Duration (months) & & & 0.159 \\
\hline Mean (SD) & $44.0(29.1)$ & $53.6(28.9)$ & \\
\hline Median & 31.5 & 49.5 & \\
\hline Range & 8-114 & $8-128$ & \\
\hline HIV stage & & & 0.061 \\
\hline I-II & 7 & 18 & \\
\hline III-IV & 23 & 22 & \\
\hline
\end{tabular}

available baseline WHO clinical staging, out of which 45 (64.3\%) children were moderately to severely symptomatic (WHO stage 3 or 4). Patients were actively followed up for a median duration of 44 months (3.7 years), range 8-128 months (0.7-10.7 years). Median treatment time for girls with HIV stage I-II was 67 months (5.6 years), ranging 21-128 months (1.8-10.7 years), which was a longer duration than boys $(p=0.055)$. Most boys were already in late stage of HIV (III-IV) when they came to clinic. Meanwhile, boys had higher improvement of CD4 with median 10.5\% $(r=3.0-45.7 ; p=0.030)$ and lower viral loads (not significant) than girls, although all HIV viruses were undetected. There were correlations between viral load and CD4 with age in boys. There were no significant effects of caregiver on the success of treatment. The antiretroviral regimen used for the 168 children enrolled based on the last visit were $76 \%$ AZT-3TC-NVP/EFZ, 8\% TDF-3TC-EFZ, and 16\% PI-based.

\section{Discussion}

This is the first study in Indonesia that shows the characteristics of children with HIV infection, who had been treated for more than 6 months. Available treatment regimens for children in Indonesia are 3FDC zidovudine-based, 3FDC tenofovir-based, and lopinavir/ritonavir. The 3FDC stavudine-based had been discontinued since early 2016. In 70 vertically infected-HIV children, the gender ratio of girl and boy was $4: 3$.

The result of European collaborative study on 3,231 babies born from HIV-infected mothers in Europe from 19862003 who did not breastfeed showed that girls had higher risk
Table 3. Comparison of viral load, CD4, and treatment duration

\begin{tabular}{|c|c|c|c|}
\hline \multirow{2}{*}{ Variable } & \multicolumn{2}{|c|}{ HIV stage } & \multirow{2}{*}{$\begin{array}{c}p \\
\text { value }^{*}\end{array}$} \\
\hline & I-II & III-IV & \\
\hline Male & $(n=7)$ & $(n=23)$ & \\
\hline Viral load & & & 0.924 \\
\hline Mean (SD) & $9.7(7.0)$ & $11.7(7.4)$ & \\
\hline Median & 6 & 6 & \\
\hline Range & $5-20$ & $5-20$ & \\
\hline CD4 & & & 0.924 \\
\hline Mean (SD) & $11.4(3.2)$ & $13.4(9.7)$ & \\
\hline Median & 10.64 & 10.48 & \\
\hline Range & $8.1-18.2$ & $0-45.7$ & \\
\hline Duration (months) & & & 0.631 \\
\hline Mean (SD) & $39.9(28.5)$ & $45.3(29.8)$ & \\
\hline Median & 27 & 33 & \\
\hline Range & $8-89$ & $12-114$ & \\
\hline Female & $(n=18)$ & $(n=22)$ & \\
\hline Viral load & & & 0.209 \\
\hline Mean (SD) & $10.4(7.0)$ & $8.7(6.3)$ & \\
\hline Median & 6 & 6 & \\
\hline Range & $5-20$ & $5-20$ & \\
\hline CD4 & & & 0.325 \\
\hline Mean (SD) & $9.8(1.5)$ & $9.2(2.3)$ & \\
\hline Median & 10.09 & 9.08 & \\
\hline Range & $6.8-11.9$ & $4.1-13.6$ & \\
\hline Duration (months) & & & 0.012 \\
\hline Mean (SD) & $65.6(26.9)$ & $43.7(27.2)$ & \\
\hline Median & 67 & 42 & \\
\hline Range & $21-128$ & $8-101$ & \\
\hline
\end{tabular}

Comparison: male vs. female

\begin{tabular}{l|l|l|l}
\hline Viral load & $p=0.790$ & $p=0.319$ & \\
\hline CD4 & $p=0.357$ & $p=0.046$ & \\
\hline Duration (months) & $p=0.055$ & $p=0.955$ & \\
\hline
\end{tabular}

$P$ value determined by Mann-Whitney test

of HIV infection than boys (odds ratio [OR] $=1.49 ; 95 \%$ CI: 1.04-2.13) that may be transmitted intrauterine [20]. The result of recent study in Kenya on 38 babies infected by HIV showed that the gender composition was $71 \%(n=27)$ girls and 29\% $(n=11)$ boys. Further analysis showed a significant association between gender and HIV prevalence $(p<0.002)$. This indicates that gender in one of the risk factors in HIV vertical transmission [21]. A study in South Africa showed that based on clinical indication, 78\% girls needed early ART, which indicated that the clinical description was worse than boys [22]. Gender affects the incidence of many infectious transmitted diseases [23]. Hormonal, genetic, and environmental factors contribute to HIV infection in girls [21-23]. 
Table 4. Correlation between viral load and CD4 with age and duration of treatment

\begin{tabular}{|c|c|c|c|c|}
\hline \multirow[b]{2}{*}{ Correlation } & \multicolumn{2}{|c|}{ Age (year) } & \multicolumn{2}{|c|}{ Duration of treatment } \\
\hline & $\begin{array}{c}\text { Coefficient } \\
\text { correlation } \\
\text { (r) }\end{array}$ & $p$ value & $\begin{array}{c}\text { Coefficient } \\
\text { correlation } \\
\text { (r) }\end{array}$ & $p$ value \\
\hline \multicolumn{5}{|l|}{ Male $(n=30)$} \\
\hline Viral load & 0.387 & 0.035 & 0.376 & 0.041 \\
\hline CD4 & -0.082 & 0.668 & 0.037 & 0.846 \\
\hline \multicolumn{5}{|c|}{ Female $(n=40)$} \\
\hline Viral load & -0.029 & 0.858 & 0.054 & 0.739 \\
\hline CD4 & 0.244 & 0.129 & -0.003 & 0.986 \\
\hline
\end{tabular}

Table 5. Correlation of CD4 and viral load with caregiver

\begin{tabular}{|c|c|c|c|c|}
\hline \multirow[b]{2}{*}{ Variable } & \multicolumn{3}{|c|}{ Caregiver } & \multirow[b]{2}{*}{$\begin{array}{c}p \\
\text { value* }\end{array}$} \\
\hline & $\begin{array}{c}\text { Parent } \\
(n=30)\end{array}$ & $\begin{array}{l}\text { Grandparent } \\
\qquad(n=40)\end{array}$ & Others & \\
\hline CD4 & & & & 0.542 \\
\hline Mean (SD) & $\begin{array}{c}36.0 \\
(2.72)\end{array}$ & $\begin{array}{l}3.79 \\
(3.0)\end{array}$ & $\begin{array}{c}3.36 \\
(2.93)\end{array}$ & \\
\hline Median & 4.0 & 3.47 & 2.40 & \\
\hline Range & $1-8.4$ & $1.8-9.6$ & $7.2-8.4$ & \\
\hline Viral load & & & & 0.875 \\
\hline Mean (SD) & $\begin{array}{l}10.3 \\
(6.9)\end{array}$ & $\begin{array}{l}10.3 \\
(7.2)\end{array}$ & $\begin{array}{l}10.4 \\
(7.2)\end{array}$ & \\
\hline Median & 6 & 6 & 6 & \\
\hline Range & $5-20$ & $5-20$ & $5-20$ & \\
\hline
\end{tabular}

$P$ value determined by Kruskal-Wallis test

High incidence of HIV in girls from their mothers showed that virus had target preference from in utero, at the conception time until birth. Girls were at higher risk of early (in utero and perinatal) HIV infection than boys. Studies showed that there is a minor histocompatibility reaction between infant $\mathrm{Y}$ chromosome-derived antigens and maternal lymphocytes, which can reduce the risk of HIV transmission in boys [24]. The plasmacytoid dendritic cells in woman produce more IFN- $\alpha$ than man in time of HIV infection, which makes HIV progressivity faster [25].

Vertical HIV infection from mother to child is more frequent in mother-to-daughter, and more male fetuses die in utero or after birth. Recent studies showed a high mortality in HIV-infected male fetuses compared with female fetuses, resulting in more female babies born with HIV. Gonadal steroid production appears to play a role as an immunosuppressant since conception [23]. A study carried out in Africa demonstrated that HIV-infected male fetuses has higher mortality rate, including deaths caused by other intrauterine infection, prematurity, and respiratory distress. This results in lower survival ability in male fetuses than females' [26].
Neonatal mortality rate in Indonesia per 1,000 live births was 14.4 in 2013; unfortunately, there is no data available to compare genders [27]. In 2015, total infant mortality rate in Indonesia was 23.5 deaths per 1,000 live births, with male vs. female ratio $3: 2$ [28]. That could explain the gender composition in this study 4 (girls) : 3 (boys), more girls enrolled than boys.

A study conducted by Ruel et al. on 670 vertically HIV-infected children aged $<18$ years old suggested that girls had a lower viral load $(p<0.0004)$ and higher percentage of CD4 than boys [29]. The results could not be compared with this study because the subjects of Ruel's trial have not received ARV therapy. There are several studies suggesting that HIV viral load in girls who received ARV is 0.38 log lower than in boys; however, the difference in percentage of CD4 was not statistically significant either in boys or girls [30]. A study of 1,244 children who had received ART showed a decrease of viral load, either in boys or girls; however, there was also no statistically significant difference between the sexes $(p=0.26)$ [22]. Systematic reviews from 65 articles of adult patients who have received ART, included 39 studies conducted in South America and Europe, 26 studies in Latin America, Asia, and Africa. Forty-four studies (68\%) comparing gender with mortality risk and HIV progressivity with AIDS showed that either viral load or immunology outcome were not statistically significant. Investigation of 24 articles demonstrated a significant reduction in mortality in female patients who have received ART when compared with men [30]. All children in our study reached therapeutic success with the level of virus undetected [6].

This study showed that boys could achieve a successful outcome treatment compare with girls by age $(p=0.035)$, and shorter duration of treatment than girls $(p=0.041)$. The result is due to different genetic conditions between men and women. In addition, the condition of the immune system in women and men is also different; CD4 levels are better in the males' group than females'. The condition of CD4 and better immune response in men may affect the length of duration of therapy required to achieve expected conditions. The results of this study enrich the study of gender differences in infected-HIV children; boys were able to achieve therapeutic success outcome by taking their medications regularly without paying attention to their caregivers.

There are certain limitations to be considered in our study. Children lost to follow-up may have been died without reporting this fact, resulting in an underestimation of mortality. On the other hand, our clinic is a referral center, thus more children with advanced HIV disease were enrolled. Strong point of this study is the representation of real world in HIV children care in limited resources, with a considerably long duration of follow-up. In addition, coverage of HAART in our clinic was free of charge but not included other health services such as patient registration, counseling, and laboratory testing. This practical aspect makes difficult to detect failure of therapy. In the meantime, we had patients with long-term good adherence treatment and the results were quite a success. 


\section{Conclusions}

Although most children receive HAART when they have advanced HIV infections, they can achieve virology control even in area with limited resources. Children, especially boys, can achieve successful therapeutic results when they have a good adherence to treatment and take the medication regardless of guardian. Long-term follow-up of the children is necessary and needs to be supported.

\section{Conflict of interest}

The authors declare no potential conflicts of interest with respect to the research, authorship, and/or publication of this article.

\section{References}

1. UNAIDS. Global report: UNAIDS report on the global AIDS epidemic 2012. WHO Press, Genewa 2012.

2. UNICEF. Annual report, 2015.

3. UNAIDS. The gap report, 2014.

4. UNICEF-Indonesia. Issue Brief Responding to HIV and AIDS. UNICEF-Indonesia, Jakarta 2012.

5. Ditjen PPKR. Statistik kasus HIV/AIDS di Indonesia dilaporkan s/d September 2014. Sistem Informasi HIV-AIDS \& IMS (SIHA). Kemenkes RI, Jakarta 2014.

6. WHO. Consolidated guidelines on the use of antiretroviral drugs for treating and preventing HIV infection. Recommendations for a public health approach. WHO, Geneva 2013.

7. Song R, Jelagat J, Dzombo D, et al. Efficacy of highly active antiretroviral therapy in HIV-1 infected children in Kenya. Pediatrics 2007; 120: e856-861.

8. Phongsamart W, Hansudwechakul R, Bunupuradah T, et al. Longterm outcomes of HIV-infected children in Thailand: the Thailand Pediatric HIV Observational Database. Int J Infect Dis 2014; 22: 19-24.

9. Mukherjee A, Shah N, Singh R, et al. Outcome of highly active antiretroviral therapy in HIV-infected Indian children. BMC Infect Dis 2014; 14: 701-708.

10. Dollfus C, Le Chenadec J, Faye A, et al. Long-term outcomes in adolescents perinatally infected with HIV-1 and followed up since birth in the French perinatal cohort (EPF/ANRS CO10). Clin Infect Dis 2010; 51: 214-224.

11. Chantry CJ, Byrd RS, Englund JA, et al. Growth, survival and viral load in symptomatic childhood human immunodeficiency virus infection. Pediatr Infect Dis J 2003; 22: 1033-1039.

12. McGrath CJ, Diener L, Richardson BA, et al. Growth reconstitution following antiretroviral therapy and nutrition supplementation: systematic review and meta-analysis. AIDS 2015; 29: 2009-2023.

13. Cruz MLS, dan Cardoso CA. Perinatally infected adolescents living with human immunodeficiency virus (perinatally human immunodeficiency virus). World J Virol 2015; 4: 277-284

14. Jesson J, Koumakpaï S, Diagne NR, et al. Effect of age at antiretroviral therapy initiation on catch-up growth within the first 24 months among HIV-infected children in the IeDEA West African pediatric cohort. Pediatr Infect Dis J 2015; 34: e159-168.

15. Feinstein L, Yotebieng M, Moultrie H, et al. Effect of baseline immune suppression on growth recovery in HIV positive South African children receiving antiretroviral treatment. J Acquir Immune Defic Syndr 2012; 61: 235-242.

16. Yuh B, Tate J, Butt AA, et al. Weight change after antiretroviral therapy and mortality. Clin Infect Dis 2015; 60: 1852-1859.
17. The European Collaborative Study. Height, weight, and growth in children born to mothers with HIV-1 infection in Europe. Pediatrics 2003; 111: e52-e60.

18. Barry O, Powell J, Renner L, et al. Effectiveness of first-line antiretroviral therapy and correlates of longitudinal changes in $\mathrm{CD} 4$ and viral load among HIV-infected children in Ghana. BMC Infect Dis 2013; 12: 476-486.

19. McMahon JH, Elliott JH, Bertagnolio S, et al. Viral suppression after 12 months of antiretroviral therapy in low- and middle-income countries: a systematic review. Bull World Health Organ 2013; 91: 377-385.

20. Thorne C, dan Newell ML. Are girls more at risk of intrauterineacquired HIV infection than boys? European Collaborative Study. AIDS 2004; 18: 329-347.

21. Khobondo JO, Gicheru MM, Khamadi SA. Pediatric HIV-AIDS in Nairobi: prevalence, gender and implication for prevention of mother to child transmission. Eur J Res Med Sci 2015; 3: 52-59.

22. Mori M, Adland E, Paioni P, et al. Sex Differences in Antiretroviral Therapy Initiation in Pediatric HIV Infection. PLoS One 2015; 10: e0131591.

23. Muenchhoff M, Goulder PJR. Sex differences in pediatric infectious diseases. J Infect Dis 2014; 209 Suppl 3: S120-126.

24. Schechter M, Tuboi SH. Discordant immunological and virological responses to antiretroviral therapy. J Antimicrob Chem 2006; 58: 506-510.

25. Meier A, Chang JJ, Chan ES, et al. Sex differences in the toll-like receptor-mediated response of plasmacytoid dendritic cells to HIV-1. Nat Med 2009; 15: 955-959.

26. Taha TE, Nour S, Kumwenda NI. Gender differences in perinatal HIV acquisition among African infants. Pediatrics 2005; 115: 167-172.

27. UNICEF/WHO/The World Bank/UN Pop Div. Levels and Trends in Child Mortality. Report 2014.

28. UN Inter-agency Group for Child Mortality Estimation (UNICEF, WHO, World Bank, UN DESA Population Division). Available at: www.childmortality.org. 2016.

29. Ruel TD, Zanoni BC, Ssewanyana I, et al. Sex Differences in HIV RNA Level and CD4 Cell Percentage During Childhood. Clin Infect Dis 2011; 53: 592-599.

30. Castilho JL, Melekhin VV, Sterling TR. Sex differences in HIV outcomes in the highly active antiretroviral therapy era: A systematic review. AIDS Res Hum Retroviruses 2014; 30: 446-456. 